\title{
ASSESSMENT OF MAIN LIST STOCKS AS AN INVESTMENT OBJECT IN THE BALTIC REGULATED MARKET
}

\author{
Inta Kotane \\ Mg.oec., lecturer, researcher, Rezekne Academy of Technologies, Rezekne, Latvia, \\ e-mail: inta.kotane@rta.lv
}

\begin{abstract}
The stock market, which could be seen as one of the types of securities market, is an unstructured environment in which every investor needs to understand how to invest. For a potential investor interested in shares as one of the objects of investment, it is possible to buy the shares and potentially earn despite the fact that an investment in shares is considered to be a very high-risk investment. The research aims to assess Baltic Main List stocks as an investment object in the Baltic regulated market. The research results showed that investors should assess and invest in the companies of the Baltic Main List on Nasdaq Vilnius and Nasdaq Riga if they plan to gain income from an increase in share prices and to assess and invest in the companies of the Baltic Main List on Nasdaq Tallinn and Nasdaq Riga if they plan to earn income from dividends. The author concludes that the use of an investment account has not been sufficiently popularised among individuals, which does not contribute to the development of savings culture in Latvia and in the other Baltic States. For the education of private investors and the promotion of making decisions on share purchases, it would be desirable for investors to offer summarised information on company shares and their characteristics on the Nasdaq website. The research employed general quantitative and qualitative methods for economic research, including comparative analysis and synthesis, statistical analysis and graphic analysis.
\end{abstract}

Keywords: stock market, investment, assessment, main list.

JEL code: G11, 016.

\section{Introduction}

In the financial world, investment in shares is considered a very highrisk investment (Pelane, 2015), and a stock market is an unstructured environment in which every investor needs to understand how to invest (Springíis, 2016). If investing in financial assets, it is recommended investing the funds that are not immediately needed (Apinis, 2015) to buy shares when others want to sell them, investing no more than $5 \%$ to $10 \%$ of the savings in the shares, investing only in the companies whose field of activity is well known and making only long-term investments (10 years) (Grišins, 2018).

An analysis of the results of stock market research by foreign scientists (Zhang, 2017; Tsagkanos, 2017; Sivaramakrishnan et al., 2017; Zaremba, Shemer, 2018; Zhong, 2018) shows that the scientists focused on stock market development and the factors affecting it (stock liquidity, investor behaviour patterns, financial literacy, risks etc.). Research studies on the securities market of Latvia, including the stock market, focused on 
opportunities for agricultural companies to raise capital in the stock market of Latvia (Kesteris - Mālkalns, 2007), trends and problems in the securities market of Latvia (Šnepste, 2011), development scenarios for the Baltic stock market (Žuka, 2009) and the effect of credibility of financial performance of Baltic companies on their share earnings (Grigorjeva, 2008).

The author believes that activity in the stock market could be raised by increasing the financial literacy of existing and potential investors. Financial literacy is a set of knowledge and skills that enables a person to understand and successfully manage their finances and take informed decisions on the choice and use of various financial services, thereby ensuring their private financial stability and sustainability (Latvijas iedzīvotāju..., 2014). Researching financial literacy (Sivaramakrishnan et al., 2017), it was concluded that the investor's behaviour was significantly influenced by unbiased financial literacy, i.e. the investor's actual knowledge.

In the author's opinion, the stock market as an investment object is undervalued. Investment in shares traded on the stock exchange could be one of the investment alternatives, which, in its turn, determines the need for financial literacy.

The Baltic regulated stock market is composed of the companies of the Main and Secondary Lists traded on all the Baltic stock exchanges: Nasdaq Tallinn, Nasdaq Riga and Nasdaq Vilnius. The author of the research has assessed the companies of the Baltic Main List that, compared with the companies of the Baltic Secondary List, are subject to quantitative requirements or restrictions on their capitalisation or the number of shares in free circulation.

The research aims to assess Baltic Main List stocks as an investment object in the Baltic regulated market.

Specific research tasks:

1. To examine changes in stock market prices in the Baltic States;

2. To assess investments in the companies of the Baltic Main List in the Baltic regulated market.

Analysis period: 2014-2018.

The research employed general quantitative and qualitative methods for economic research, including comparative analysis and synthesis, statistical analysis and graphic analysis.

\section{Changes in stock market prices in the Baltic States}

Every shareholder looks forward to the "value added" of his/her investments and to earning from two sources - share price increase or invested capital value increase and dividend payments. In the stock market, 
more focus is usually placed on the shares whose price changes are the largest.

A stock market index is a measurement of the total value of the stock market or its section based on average prices. It represents a weighted average, as more expensive shares have higher weights and are more affected by the index than lower price shares. Investors use the stock index to identify the state of the market and compare gains from various investments (Capital.com, 2018).

The Nasdaq data (Figure 1) show that between 01/01/2014 and $31 / 12 / 2018$, the stock market index OMX Riga increased by $101.9 \%$, which was the best performance among the stock market indices of the Baltic States.

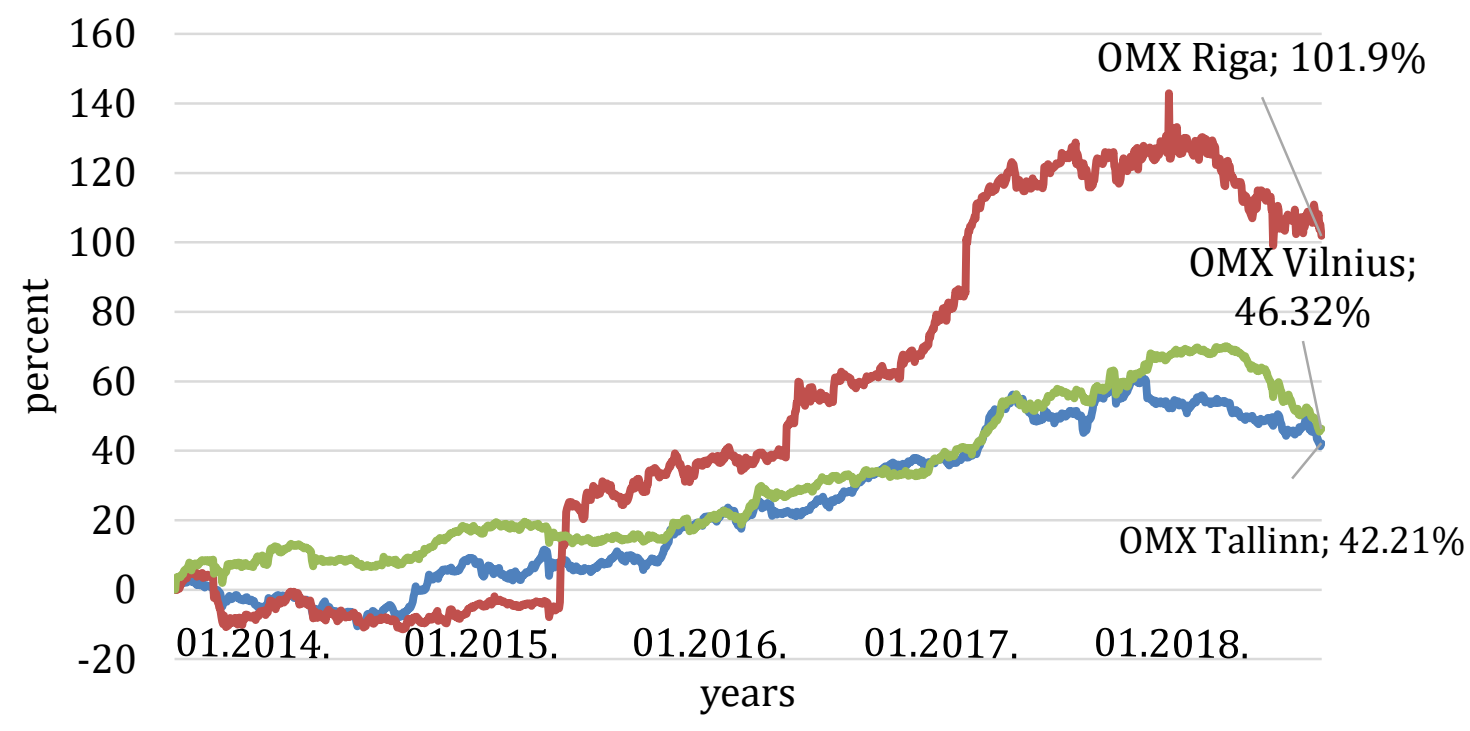

Fig.1 Changes in the Baltic stock market indices in 2014-2018, \% (compiled by the author based on Nasdaq, 2019)

In an assessment of the changes in share prices of companies in the Baltic regulated stock market in 2014-2018, the author included only the companies whose shares were traded on the stock exchange at the end of September 2019. In terms of share price increase in the period 2014-2018, the top three most liquid companies listed on Nasdaq Vilnius were as follows: JSC Šiaulių bankas, JSC AUGA group and JSC Grigeo (Table 1). In terms of share price decrease in the same period, the top three companies were JSC Baltika listed on Nasdaq Tallinn and JSC Pieno žvaigždès and JSC Panevėžio statybos trestas listed on Nasdaq Vilnius.

The author concludes that in the period 2014-2018 in the Baltic regulated stock market, the stock prices of Baltic Main List companies quoted on Nasdaq Vilnius increased the most. 
Table 1 Stock prices of companies of the Baltic Main List in the Baltic regulated market in 2014-2018 (compiled by the author based on Nasdaq, 2019)

\begin{tabular}{|c|c|c|c|c|}
\hline Share issuer, JSC & $\begin{array}{c}\text { Share price } \\
\text { change, } \%\end{array}$ & $\begin{array}{c}\text { Closing } \\
\text { price, end of } \\
2018 \\
\end{array}$ & $\begin{array}{l}\text { Highest } \\
\text { price, } \\
\text { EUR }\end{array}$ & $\begin{array}{c}\text { Lowest } \\
\text { price, } \\
\text { EUR }\end{array}$ \\
\hline \multicolumn{5}{|c|}{ Nasdaq Riga } \\
\hline Grindeks & -28.62 & 6.5 & 10.5 & 3.96 \\
\hline HansaMatrix & 9.66 & 6.5 & 8.83 & 6.05 \\
\hline Olainfarm & -5.06 & 6.7 & 11.5 & 5.5 \\
\hline SAF Tehnika & +1.91 & 2.32 & 7.92 & 1.41 \\
\hline \multicolumn{5}{|c|}{ Nasdaq Vilnius } \\
\hline AUGA group & +100 & 0.4 & 0.645 & 0.195 \\
\hline Energijos Skirstymo Operatorius & -26.78 & 0.648 & 0.93 & 0.638 \\
\hline Grigeo & +87.41 & 1.325 & 1.585 & 0.675 \\
\hline Ignitis gamyba & +26.9 & 0.5 & 0.94 & 0.395 \\
\hline Klaipèdos nafta & +40.41 & 0.41 & 0.705 & 0.28 \\
\hline Linas Agro Group & -6.71 & 0.64 & 0.825 & 0.59 \\
\hline Novaturas & -31.03 & 8 & 12.78 & 7.9 \\
\hline Panevėžio statybos trestas & -33.45 & 0.752 & 1.34 & 0.75 \\
\hline Pieno žvaigždès & -50.27 & 0.93 & 2.13 & 0.91 \\
\hline Rokiškio sūris & +57.86 & 2.51 & 2.99 & 1.3 \\
\hline Šiaulių bankas & +205.53 & 0.401 & 0.564 & 0.262 \\
\hline Telia Lietuva & +8.05 & 1.105 & 1.17 & 0.7 \\
\hline Vilkyškių pieninè & +30.57 & 2.05 & 3.94 & 1.35 \\
\hline \multicolumn{5}{|c|}{ Nasdaq Tallinn } \\
\hline Arco Vara & -19.54 & 1.12 & 1.6804 & 0.821 \\
\hline Apranga & -38.46 & 1.6 & 3 & 1.57 \\
\hline Baltika & -70.02 & 0.4087 & 1.5676 & 0.156 \\
\hline EfTEN Real Estate Fund III & +2.53 & 16.2 & 17.3 & 14.9 \\
\hline Ekspress Grupp & -8.77 & 1.04 & 1.47 & 0.789 \\
\hline Harju Elekter & +52.59 & 4.12 & 6.68 & 2.43 \\
\hline LHV Group & +34.76 & 9.4152 & 11.8437 & 7 \\
\hline Merko Ehitus & +27.78 & 9.2 & 11.8 & 6.7 \\
\hline Nordecon & -15.24 & 0.89 & 1.46 & 0.885 \\
\hline PRFoods & -12.86 & 0.61 & 0.855 & 0.349 \\
\hline Pro Kapital Grupp & -26.79 & 1.64 & 2.8 & 1.54 \\
\hline Silvano Fashion Group & -13.48 & 2.31 & 3.18 & 1.1 \\
\hline Tallink Grupp & +14.04 & 1.015 & 1.275 & 0.59 \\
\hline Tallinna Kaubamaja Grupp & +58.87 & 8.42 & 10.25 & 4.79 \\
\hline Tallinna Sadam & +5.81 & 2.04 & 2.179 & 1.91 \\
\hline Tallinna Vesi & -19.33 & 9.6 & 15.6 & 8.52 \\
\hline
\end{tabular}

The Nasdaq statistical data indicate that in the period JanuarySeptember 2019, the highest share price increase was reported for JSC Grindeks $-86.15 \%$ and JSC SAF Tehnika $-72.41 \%$, whereas the lowest share 
price decrease was reported for JSC Baltika - 71.5\% (Nasdaq, 2019). The price fluctuation of company stocks in the analysis period was mainly determined by the microeconomic factors affecting stock prices (company financial situation, company management decisions etc.).

The author concludes that the investors who expect to gain from stock price increases should assess and invest in the companies of the Baltic Main List quoted on Nasdaq Vilnius.

In the author's opinion, if considering buying shares, a stock market price change assessment could be used to get an initial view of the company, yet a comprehensive analysis of the potential investment in the company should be performed before investing in the shares.

\section{Assessment of investment in Baltic Main List shares in the Baltic regulated market}

If an investor fails to earn on stock price increases in a short term, the investor has a chance not to make active investments in the hope of rising prices and to buy the stocks with the aim of receiving dividends. Investors whose preliminary knowledge of stock exchanges are not sufficient can buy stocks yielding high dividends (Apinis, 2015). In the period when the largest banks of Latvia are paying interest from 0.1 to $0.5 \%$ on a deposit, the acquisition of stocks of Latvian companies that pay dividends provides income from 2-3 to 8-10 percent a year, not to mention instances where the dividends sometimes reach 20\% (Pavlovs, 2013).

Two groups of measures could be employed to assess investments in stocks:

- comparative measures of profit: earnings per share (EPS) and price earnings ratio $(\mathrm{P} / \mathrm{E})$;

- comparative measures of dividends: dividend per share and earnings per share (Dann, 2006).

Some researchers (Islam et al., 2014) have found that EPS is generally considered to be the most important factor in determining the price of shares and the value of a company and the majority of individual investors make individual investment decisions based directly on the EPS. Kumar (2017) pointed out that EPS is a strong predictor of share prices, while the P/E ratio can considerably affect forecasts of share prices of particular companies. Another researcher (Cochrane, 2011) believes that fluctuations in dividends relate to expected profits rather than expected increases in dividends.

EPS (Kumar, 2017) shows net profit per common share (Equation 1).

$$
\mathrm{EPS}=\frac{\text { reporting period net profit }}{\text { number of common shares issued }}
$$


The $\mathrm{P} / \mathrm{E}$ ratio (Kumar, 2017) indicates how much shareholders are willing to pay per unit of the company's net profit (Equation 2).

$$
\mathrm{P} / \mathrm{E}=\frac{\text { share price }}{\text { earnings per share (EPS) }}
$$

Dividend yield (Investing Answers, 2019) is a measure of return on share investment or an "interest rate" (Equation 3).

$$
\text { Dividend yield, } \%=\frac{\text { dividend per share }}{\text { share price }} \times 100
$$

By buying the shares of a company, shareholders look forward to improvement in the financial position of the company and higher share yields. The author identified the dividends paid by the companies of the Baltic Main List in the Baltic regulated market in 2018 as an initial prerequisite for assessing investment in stocks (Table 2).

Table 2 Assessment of investment in the stocks of companies of the Baltic Main List in the Baltic regulated market at the end of 2018 (compiled and calculated by the author based on Nasdaq, 2019)

\begin{tabular}{|l|c|c|c|c|c|}
\hline \multicolumn{1}{|c|}{ Share issuer, JSC } & $\begin{array}{c}\text { Share } \\
\text { price, } \\
\text { EUR }\end{array}$ & $\begin{array}{c}\text { Dividend } \\
\text { per share, } \\
\text { EUR }\end{array}$ & $\begin{array}{c}\text { EPS, } \\
\text { EUR }\end{array}$ & $\begin{array}{c}\text { Dividend } \\
\text { yield, } \\
\%\end{array}$ & P/E \\
\hline Grindeks & 6.5 & 0.15 & 1.2 & 2.31 & 5.42 \\
\hline HansaMatrix & 6.5 & 0.08 & 0.92 & 1.23 & 7.07 \\
\hline Silvano Fashion Group & 2.31 & 0.5 & 0.30 & 21.65 & 7.7 \\
\hline Tallink Grupp & 1.015 & 0.03 & 0.06 & 2.96 & 16.92 \\
\hline Ekspress Grupp & 1.04 & 0.07 & 0.00 & 6.73 & - \\
\hline Tallinna Vesi & 9.6 & 0.36 & 1.21 & 3.75 & 7.93 \\
\hline Nordecon & 0.89 & 0.06 & 0.11 & 6.74 & 8.09 \\
\hline Merko Ehitus & 9.2 & 1 & 1.09 & 10.87 & 8.44 \\
\hline Arco Vara & 1.12 & 0.01 & -0.06 & 0.89 & -18.66 \\
\hline Harju Elekter & 4.12 & 0.24 & 0.09 & 5.83 & 45.78 \\
\hline LHV Group & 9.42 & 0.16 & 0.97 & 1.70 & 9.71 \\
\hline EfTEN Real Estate Fund III & 16.2 & 0.68 & 1.96 & 4.20 & 8.27 \\
\hline Tallinna Kaubamaja Grupp & 8.42 & 0.69 & 0.75 & 8.19 & 11.23 \\
\hline Pro Kapital Grupp & 1.64 & 0.015 & 0.30 & 0.91 & 5.45 \\
\hline
\end{tabular}

As shown in Table 2, an opportunity to earn dividends was provided by only 14 out of 33 companies of the Baltic Main List, which were quoted on the stock exchange at the end of September 2019, in the Baltic regulated market (at the end of 2018, 39 companies were quoted on the stock exchange). It has to be noted that the stock prices of companies included in 
Table 2 were not among those included in Table 1 that performed the best or the worst. An analysis reveals that at the end of 2018, JSC EfTEN Real Estate Fund III had the highest share price, at EUR 16.20. Shareholders received the highest dividends from JSC Merko Ehitus; JSC EfTEN Real Estate Fund III had the highest EPS, while JSC Silvano Fashion Group had the highest dividend yield.

When making investments, investors often pay attention to the $\mathrm{P} / \mathrm{E}$ ratio. According to the data on companies for 2018, a longer payback period for an investment at a given stock market price and current profit could be observed for JSC Harju Elekter - 45.78 years. JSC Arco Vara suffered losses in 2018; therefore, its EPS was negative. A payback period for an investment in the shares of JSC Grindeks at a given stock market price and current profit could be 5.42 years. The longer the payback period for an investment, the more expensive the shares of a given company could be considered.

As shown in Table 2, investors whose preliminary knowledge of stock exchanges are not sufficient could buy the shares of JSC Silvano Fashion Group (high earnings) and JSC Grindeks (short payback period for an investment). The share prices of JSC Grindeks increased the most in JanuarySeptember 2019, which was determined by the dividends paid by this company that were the highest for the Baltic Main List in the Baltic States until the end of Septermber 2019, at EUR 1.28 per share. It has to be added that in 2019, one Nasdaq Tallinn company - JSC Šiaulių bankas - also paid dividends - EUR 0.029 per share. The author concludes that shareholders expecting to earn dividend income should assess and invest in the companies of the Baltic Main List on Nasdaq Tallinn and Nasdaq Riga.

From 1 January 2018 onwards, amendments to the law of the Republic of Latvia "On Personal Income Tax" (PIT) stipulate the investment account regime that makes it substantially easier for the natural persons who make transactions in financial instruments to calculate and declare the tax. According to the new investment account regime, PIT is not applicable if the amount of funds paid out of the account does not exceed the amount of funds paid in. The administrative burden for taxpayers is reduced in relation to transaction accounting and filing tax returns. However, if a person makes transactions in financial instruments but does not have a declared investment account, the regular procedure of PIT taxation is applicable to that person, which requires the person to quarterly or annually declare capital gains and to pay the PIT (Lasmane, 2018). In the author's opinion, the use of an investment account is not sufficiently popularised, which does not contribute to the formation of investment culture in Latvia and in the other Baltic States.

Experts admit that large and liquid companies are needed for faster development of the securities market of Latvia (Hāka, 2017). There are 
considered opportunities to improve the situation in the capital market of Latvia and effectively employ "fintech" experience: lowering costs for holding/trading securities; lowering costs for share issuers and disclosing information (Kaužēns, 2018).

The activity of private investors in the domestic securities market, including the stock market, is very important and can significantly contribute to the development of the capital market as a whole. In the author's opinion, it would be desirable for investors to offer summarised information on company stocks and their characteristics to educate private investors and to facilitate their decision-making on the purchase of stocks.

\section{Conclusions and suggestions}

In terms of share price increase in the period 2014-2018, the top three most liquid companies of the Baltic Main List were quoted on Nasdaq Vilnius: JSC Šiaulių bankas, JSC AUGA group and JSC Grigeo. In terms of share price decrease in the same period, the top three companies of the Baltic Main List were JSC Baltika quoted on Nasdaq Tallinn and JSC Pieno žvaigždės and JSC Panevėžio statybos trestas quoted on Nasdaq Vilnius. In the period 20142018, the largest increase or decrease in stock prices or an increase or decrease in the value of invested capital was observed for the Baltic Main List of Nasdaq Vilnius. The fluctuation of stock prices in the analysis period was mainly determined by the microeconomic factors which affected the stock prices.

An analysis of the companies that paid dividends at the end of 2018 shows that the highest share price was reported for JSC EfTEN Real Estate Fund III, at EUR 16.20 per share. Shareholders received the highest dividends from JSC Merko Ehitus; JSC EfTEN Real Estate Fund III had the highest EPS, while JSC Silvano Fashion Group had the highest dividend yield. A payback period for an investment in the shares of JSC Grindeks at a given stock market price and current profit could be 5.42 years. Investors whose preliminary knowledge of stock exchanges are not sufficient could buy the shares of JSC Silvano Fashion Group and JSC Grindeks.

Based on an assessment of changes in stock prices and of dividends paid by the companies of the Baltic Main List in the Baltic regulated market in 2014-2018 and January-September 2019, investors should consider and invest in:

- the Baltic Main List on Nasdaq Vilnius and Nasdaq Riga if they plan to gain income from an increase in stock prices;

- the Baltic Main List on Nasdaq Tallinn and Nasdaq Riga if they intend to earn income from dividends. 
The use of an investment account has not been sufficiently popularised among individuals, which does not contribute to the development of savings culture in Latvia and in the other Baltic States.

For the education of private investors and the promotion of making decisions on share purchases, it would be desirable for investors to offer summarised information on company shares and their characteristics on the Nasdaq website.

\section{References}

1. Apinis, M. (2015). Biržs vilina ar peḷnu. Ifinanses. Aprīlis. Nr.1. 36.-39.lpp.

2. Capital.com (2018). Akciju indekss. Pieejams: https://capital.com/lv/akcijuindekss-definicija

3. Cochrane, J.H. (2011). Presidential address: discount rates. Journal of finance. 66. pp.1047-1108. Retrieved from from https://ej.uz/fpm9

4. Danns, F. (2006). Ieguldïjumu akcijās vērtēšana (1.dal̦a). Finansists. 1 (13). 12.13.lpp.

5. Grigorjeva, J. (2008). Baltijas valstu uzñēmumu finanšu rezultātu ticamības ietekmes uz akcijas ienesīgumu novērtēšana. RTU. 112 lpp.

6. Grišins, J. (2018). Kur zemo depozìtu likmju laikā ieguldìt 1000 eiro. Dienas Bizness. 19.06.2018.

7. $\quad$ Hāka, Ž. (2017). Neizmanto visu potenciālu. Dienas Bizness. 18.12.2017.

8. Investing Answers (2019). Dividend yield. Retrieved from https://ej.uz/fkaq

9. Islam, Md. R., Khan, T. R., Choudhury, T.T., Adnan, A.M. (2014). How Earning Per Share (EPS) Affects on Share Price and Firm Value. European Journal of Business and management. 6(17). Retrieved from https://ej.uz/c5i7

10. Kaužēns, E. (2018). Kapitāla tirgus Latvijāa - trešajā desmitgadē, bet joprojām vājšs. Vai ir alternativvas? Pieejams: https://ej.uz/zfkz

11. Kesteris - Mālkalns, R. (2007). Lauksaimniecības uzṇēmumu iespējas piesaistīt kapitālu Latvijas akciju tirgū. LLU raksti. 19(314). 37.-53.lpp.

12. Kumar, P. (2017). Impact of earning per share and price earnings ratio on market price of share: a study on auto sector in India. International Journal of Research. Granthaalayah. 5(2), pp.113-118. DOI: https://doi.org/10.5281/zenodo.345456

13. Lasmane, A. (2018). Ko paredz ieguldījumu konta režīms? Ifinanses. Maijs

14. Latvijas iedzīvotāju finanšu pratības stratēǵija 2014-2020 (2014). Finanšu pratības mājas lapa. Pieejams: https://ej.uz/qnkg

15. Nasdaq (2019). Nasdaq Baltijas tirgus. Pieejams: https://nasdaqbaltic.com/ market/?lang=lv

16. Pavlovs, S. (2013). Kad depozìts nesilda. IrNauda Septembris. Nr.5. 52.-54.lpp

17. Pelane, A. (2015). Akciju tirgotāja ABC. Pieejams: https://ej.uz/dz7q

18. Sivaramakrishnan, S., Srivastava, M., Rastogi, A. (2017). Attitudinal factors, financial literacy and stock market participation. International Journal of Bank Marketing. 35(5). 818-841. Retrieved, from https://doi.org/10.1108/IJBM-01-2016-0012

19. Šnepste, V. (2011). Vērtspapīru tirgus Latvijā - attīstības iespējas un problēmas. Latgales Tautsaimniecības pētïjumi. Sociālo zinātñu žurnāls. 1(4). 358.-372.lpp. 
20. Springgis, J. (2016). Veiksmīga akcionāra portfeḷa veidošana. IBizness. Jūnijs. 23.26.lpp.

21. Tsagkanos, A. ((2017). Stock market development and income inequality. Journal of Economic Studies. 44(1), pp.87-98. Retrieved from https://doi.org/10.1108/JES-082015-0155

22. Zaremba, A., Shemer, J. (2018). Is there momentum in factor premia? Evidence from international equity markets. Research in International Business and Finance. 46. pp.120-130. Retrieved from https://doi.org/10.1016/j.ribaf.2017.12.002

23. Zhang, L. (2017). Local equity market participation and stock liquidity. The Quarterly Review of Economics and Finance. 63. pp.101-121. Retrieved from http://dx.doi.org/10.1016/j.qref.2016.02.005

24. Zhong, A. (2018). Idiosyncratic volatility in the Australian equity market. PacificBasin Finance Journal. 50. pp.105-125. http://dx.doi.org/10.1016/ j.pacfin.2017.06.010

25. Žuka, J. (2009). Baltijas akciju tirgus attīstības scenāriji. RTU. 93 lpp. Pieejams http://ejuz.lv/30ny 